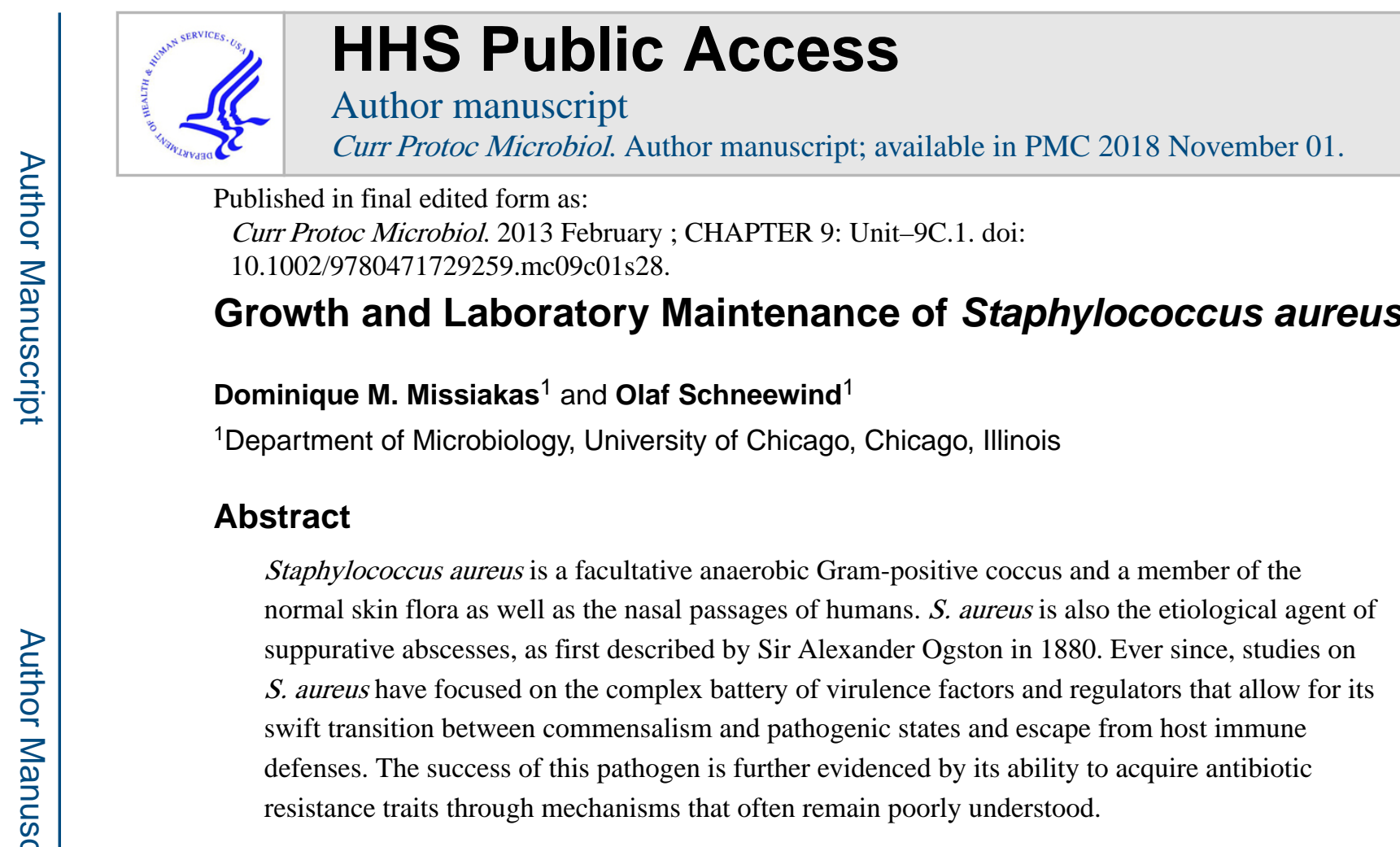

Keywords

Staphylococcus aureus; Gram positive; coccus; MRSA

\title{
INTRODUCTION
}

Using Koch's postulates for the identification of pathogenic microbes, Ogston identified the etiological agent of suppurative abscesses (Ogston, 1883). The name Staphylococcus aureus was chosen to distinguish this species with its characteristic yellow colony pigment from another staphylococcal commensal that forms white colonies (Staphylococcus albus, now designated Staphylococcus epidermidis) (Rosenbach, 1884; Götz et al., 2006). S. aureus displays several striking microbiological properties, e.g., the microbe binds immunoglobulins and agglutinates with or coagulates blood and plasma (Loeb, 1903; Much, 1908; Forsgren and Sjöquist, 1966; Cheng et al., 2011). These traits have been useful for the early and rapid diagnosis of $S$. aureus infections (for a historical account of the coagulase test, follow the link http://www.microbelibrary.org/index.php/library/laboratory-test/3220coagulase-test-protocol).

All Staphylococci grow in clusters, a feature that can be visualized by microscopy and accounts for the Greek name $\sigma \tau a \Phi \cup \lambda$ ококко $\varsigma$ or grape-like berry. Clustering is caused by the incomplete separation of daughter cells following division in three alternating perpendicular planes (Tzagoloff and Novick, 1977; Giesbrecht et al., 1998). S. aureus cells appear perfectly spherical with a diameter of $\sim 1 \mu \mathrm{m}$ (Giesbrecht et al., 1998).S. aureus also produces catalase; when applied to colony material, the catalase test is a rapid, useful test to distinguish staphylococci from other Gram-positive bacteria such as streptococci.

$S$. aureus is a facultative anaerobe that grows by aerobic respiration or by fermentation, which yields principally lactic acid. The bacterium metabolizes glucose via the pentose phosphate pathway (Reizer et al., 1998). There is no evidence for the existence of the 
Entner-Doudoroff pathway; however, enzymes of the entire tricarboxylic acid cycle and a typical F0F1-ATPase are encoded by the genome of $S$. aureus (Kuroda et al., 2001). Upon glucose depletion, $S$. aureus cells growing in aerobic conditions oxidize D-galactose, acetate, succinate and malate. An excellent summary of these metabolic pathways was recently published (Götz et al., 2006).

CAUTION: $S$. aureus is a highly virulent and adaptable pathogen with the ability to infect, invade, persist, and replicate in any human tissue including skin, bone, visceral organs, or vasculature (Lowy, 1998). The organism has been placed in Risk Group Level 2. All manipulations with $S$. aureus strains must be performed following biosafety level 2 measures including experimental work in certified biosafety cabinets. Guidelines for BSL2 practice can be obtained from the latest edition of Biosafety in Microbiological and Biomedical Laboratories (BMBL, 5th Edition) via the following CDC Web link: http://www.cdc.gov/ biosafety/publications/bmbl5/.

\section{STRATEGIC PLANNING}

\section{Strain Selection}

Owing to its niche as a commensal, $S$. aureus is readily exposed to all antibiotic therapies (Neu, 1992), which has led to the selection of drug-resistant strains commonly designated as MRSA for methicillin-resistant $\underline{S}$. $\underline{\text { aureus }}$ (see also UNIT 9C.2). Drug-sensitive strains are typically referred to as MSSA or methicillin-sensitive $S$. aureus (Brumfitt and HamiltonMiller, 1989). For several decades, vancomycin, a large glycopeptide from actinomyces (Walsh, 1993), has been the antibiotic of choice against MRSA infections (Lowy, 1998). However, vancomycin-resistant (VRSA) phenotypes have emerged and these are associated with the acquisition of resistance genes otherwise found in Enterococcus faecalis (Chang et al., 2003; Weigel et al., 2003). S. aureus strains with intermediate vancomycin resistance (VISA) have also caused therapeutic failures; it is still not clear whether VISA strains harbor stable, inheritable genetic traits that result in the spread of this resistance phenotype (Brumfitt and Hamilton-Miller, 1989; Hiramatsu et al., 1997; Chang et al., 2003). Recently, daptomycin and linezolid have been introduced as alternatives to vancomycin for the therapy of MRSA infections (Stevens et al., 2002; Arbeit et al., 2004). However, MRSA strains rapidly evolve resistance against antibiotics introduced for broad clinical use and there is continued need for the identification of drug targets and the development of new antibiotics (van Hal and Paterson, 2011). Infections with antibiotic-resistant strains are frequently acquired in hospitals (HA-MRSA), in an environment where commensals are stringently selected for resistance against these therapeutics (Brumfitt and Hamilton-Miller, 1989). Nevertheless, as the commensal spreads with human contact, MRSA infections originate with increasing frequency also in community settings (CA-MRSA; Herold et al., 1998). One specific clone, the Panton-Valentin leukocidin-positive CA-MRSA isolate USA300, has colonized many communities in the United States, triggering an epidemic outbreak of CAMRSA infections (Diep et al., 2006; Kennedy et al., 2008).

Molecular genetic and metabolic studies in $S$. aureus are best performed with an MSSA isolate to facilitate the use of antibiotic resistance markers during allelic replacement (Bae and Schneewind, 2005). MSSA strain S. aureus NCTC 8325 was deposited in the National 
Reference Center for Staphylococcus lysotyping (Institute Cantacuzino Bucharest, Romania). Iordanescu and Surdeanu used NCTC 8325 (ATCC35556) to isolate restriction and modification deficient (SA103), as well as restriction deficient and modification proficient (SA113) variants (Iordanescu and Surdeanu, 1976). SA113 and its variants have been used extensively for studies on $S$. aureus physiology and pathogenesis (von Eiff et al., 1997; Schlag et al., 2007). Novick generated $S$. aureus 8325-4 (RN450), a variant of $S$. aureus NCTC 8325 that lacks all three prophages; RN450 can be readily transduced with staphylococcal phages (Novick, 1967). S. aureus RN6390, another derivative of NCTC8325, was used to study accessory gene regulation (agr), the quorum-sensing system of staphylococcal virulence (Vandenesch et al., 1991; Novick and Geisinger, 2008). The NCTC8325 derivative $S$. aureus RN4220 is used for the genetic manipulation of plasmid DNA (Kreiswirth et al., 1983). Unlike clinical isolates, RN4220 can accept $E$. coli propagated plasmid DNA due to nitrosoguanidine-induced mutation(s) in its restrictionmodification system (Novick, 1990). The responsible mutation was recently mapped to the saulhsdR gene (Waldron and Lindsay, 2006).

Clinical MSSA isolates have been used to examine $S$. aureus virulence in animal models. $S$. aureus Newman was isolated from a throat swab and has been selected for animal studies due to its stable agr phenotype; $S$. aureus Newman has been used to elucidate the genetic requirements for staphylococcal coagulation and clumping (agglutination) in plasma, as well as abscess formation in mice (Duthie, 1954; Cheng et al., 2009). UAMS-1 (ATCC 49230) was isolated from a case of osteomyelitis and was used to study the pathogenesis of this disease in animals (Gillaspy et al., 1995). Strains Cowan 1 (isolated from a case of sepsis) and Wood 46 (dermatoxin producer) were used to examine differential binding of staphylococci to collagen. Virtually all $S$. aureus strains elaborate capsular polysaccharides, albeit that the levels of encapsulation vary considerably (O'Riordan and Lee, 2004). Strains with robust encapsulation, e.g., $S$. aureus Reynolds or $S$. aureus Smith, have been used to assess capsular polysaccharides as protective antigens (O'Riordan and Lee, 2004). In the United States, CA-MRSA strain USA300 is currently the preferred isolate for the study of MRSA virulence (Wang et al., 2007). A collection of isogenic variants in S. aureus USA300 (Nebraska Library) has been made available for distribution through the Network on Antimicrobial Resistance in Staphylococcus aureus (NARSA) repository (http:// www.narsa.net).

\section{Growth Conditions}

$S$. aureus can grow at a temperature range between $15^{\circ}$ to $45^{\circ} \mathrm{C}$ and at $\mathrm{NaCl}$ concentrations up to $15 \%$. However, extended exposures above $42^{\circ} \mathrm{C}$ or below $10^{\circ} \mathrm{C}$ are not recommended. Plates should not be stored for longer than one week at $4^{\circ} \mathrm{C}$. Owing to its highly cross-linked peptidoglycan (de Jonge et al., 1992), S. aureus is resistant to high osmolarity, detergents, as well as alcohol. Mannitol salt agar containing $7.5 \% \mathrm{NaCl}$ (most media contain $0.5 \% \mathrm{NaCl}$ ) has been used as a selective medium, as $S$. aureus is capable of fermenting mannitol.

\section{Media}

$S$. aureus produces the yellow pigment staphyloxanthin and characteristic gold-colored colonies are formed on all rich media including tryptic soy agar (TSA) at $37^{\circ} \mathrm{C}$, brain heart 
infusion (BHI) agar and Luria Bertani (LB) agar. A minimal medium for the study of amino acid auxotrophs has been described (Rudin et al., 1974). S. aureus secretes a-hemolysin, as well as several other hemolytic proteins and on plates with sheep or rabbit red blood cells, colonies are typically surrounded by multiple zones of complete and incomplete hemolysis (Bernheimer et al., 1968; Dinges et al., 2000). When propagated on Baird-Parker agar with egg yolk tellurite, $S$. aureus forms black colonies that are surrounded by a zone of lipid precipitation, caused by the secretion of glycerol-ester hydrolases (lipases) (Rosenstein and Gotz, 2000). Lee and colleagues developed an elegant genetic system for the site-specific integration of DNA into the lipase gene of $S$. aureus (Lee and Iandolo, 1986; Lee et al., 1991); this technology is very useful for complementation studies and for the controlled expression of essential genes (Gründling and Schneewind, 2007). Tellurite and lithium chloride in Baird-Parker agar inhibit the growth of most bacteria, while pyruvate and glycine specifically promote the growth of $S$. aureus. Tryptic soy broth (TSB) and BHI are the preferred media to grow cultures of Staphylococci. Cultures are grown at $37^{\circ} \mathrm{C}$ with aeration.

\section{BASIC PROTOCOL 1}

\section{GROWTH OF S. AUREUS FROM A FROZEN STOCK}

$S$. aureus is best preserved in "cryopreservation solution" (see recipe) in frozen stocks at $-80^{\circ} \mathrm{C}$. Bacteria should first be grown on solid agar when starting from a frozen stock.

Materials-S. aureus frozen stock (see Basic Protocol 3)

TSA plates with antibiotics, if necessary (see Table 9C.1.1)

Protective laboratory coat, eye goggles and disposable latex gloves

Disposable sterile loop

$37^{\circ} \mathrm{C}$ incubator

1. Work in a biosafety cabinet while wearing a protective laboratory coat, eye goggles, and disposable latex gloves. Scrape a small amount of bacteria from a frozen stock using the sterile loop (keep frozen stocks on ice or in a cooler to minimize alterations in temperature, which otherwise may affect the viability of the frozen stock).

2. Transfer the frozen aliquot of $S$. aureus onto an agar plate using the loop, streaking across the plate from left to right and top to bottom in order to obtain isolated colonies.

3. Invert the plates and incubate overnight $(12$ to $16 \mathrm{hr})$ at $37^{\circ} \mathrm{C}$. 


\section{BASIC PROTOCOL 2 \\ GROWTH OF S. AUREUS IN LIQUID MEDIUM}

Liquid cultures of $S$. aureus are used for most experiments including extraction of plasmid and chromosomal DNA, RNA, proteins, murein sacculi, and genetic manipulations, such as transposon mutagenesis, electroporation, and bacteriophage transduction.

Materials-Sterile medium (e.g., TSB, see recipe)

Antibiotics, if necessary (see Table 9C.1.1)

S. aureus colonies freshly grown on TSA (see Basic Protocol 1)

Sterile glass tubes (e.g., 18-mm) or flasks (e.g., 125-ml)

Disposable sterile loop

$37^{\circ} \mathrm{C}$ incubator with a shaker at $200 \mathrm{rpm}$ or a roller drum (tube only)

1. Add sterile medium to a sterile tube or flask and antibiotic if needed (this can be performed in the biosafety cabinet or by a sterilizing flame).

2. Working in the biosafety cabinet, pick an isolated colony from the agar plate derived from Basic Protocol 1 with the sterile loop.

3. Inoculate the sterile medium by submerging the loopful of bacteria in sterile medium and gently dispersing bacteria by moving the loop up and down the walls of the container.

4. Shake gently to suspend bacteria in solution.

5. Place the tube (upright or slightly tilted) or flask in the $37^{\circ} \mathrm{C}$ incubator on a shaker at $200 \mathrm{rpm}$ or a roller drum (tube only) and incubate for 12 to $16 \mathrm{hr}$.

\section{BASIC PROTOCOL 3}

\section{PREPARATION OF S. AUREUS FROZEN STOCKS}

S. aureus should be kept at $-80^{\circ} \mathrm{C}$ for long-term storage. Bacteria can be frozen from liquid culture in "cryopreservation solution" (i.e., 10\% glycerol). Our laboratory uses sterilefiltered 5\% bovine serum albumin, 5\% mono-sodium glutamate to freeze and store staphylococcal colony material.

Materials-S. aureus freshly grown on TSA (see Basic Protocol 1)

S. aureus freshly grown in TSB

$50 \%$ and $10 \%$ glycerol, sterile

$1 \times$ or $2 \times$ cryopreservation solution (see recipe)

Sterile pipets

Curr Protoc Microbiol. Author manuscript; available in PMC 2018 November 01. 
2-ml sterile cryogenic vials

Sterile loop

$-80^{\circ} \mathrm{C}$ freezer

1. Starting from a liquid culture:

a. Using a sterile pipet transfer $0.9 \mathrm{ml}$ of a culture into a 2-ml sterile cryogenic vial with $0.2 \mathrm{ml}$ of $50 \%$ (v/v) glycerol.

b. Alternatively, add $0.5 \mathrm{ml}$ of a culture into a 2-ml sterile cryogenic vial with $0.5 \mathrm{ml}$ of $2 \times$ cryopreservation solution.

2. Starting from a plate:

a. Scrape colonies with sterile loop and suspend into a 2-ml sterile cryogenic vial with $1 \mathrm{ml}$ of $10 \%$ glycerol made in water or broth.

b. Alternatively, suspend colonies into a 2-ml sterile cryogenic vial with 1 $\mathrm{ml}$ of $1 \times$ cryopreservation solution.

3. Close the tube and mix the solution by inverting the tube (tap down tube when done to avoid trapping frozen pellets in the cap of the tube).

4. Store the cryogenic vial in a $-80^{\circ} \mathrm{C}$ freezer for 10 years or more.

\section{REAGENTS AND SOLUTIONS}

Use deionized, distilled water in all recipes and protocol steps.

Cryopreservation solution, $1 \times$ or $2 \times-$ To prepare the $1 \times$ solution, combine $5 \%(w / v)$ mono-sodium glutamate and $5 \%(\mathrm{w} / \mathrm{v})$ bovine serum albumin with water. To generate a $2 \times$ solution, combine $10 \%(\mathrm{w} / \mathrm{v})$ mono-sodium glutamate and $10 \%(\mathrm{w} / \mathrm{v})$ bovine serum albumin with water. Stir gently using a magnetic bar and magnetic stirrer (avoid generating foam). Sterilize with a $0.22-\mu \mathrm{m}$ filter and store for up to 1 year at $4^{\circ} \mathrm{C}$.

Plate preparation-All solid media can be re-dissolved in a microwave oven. Let the medium cool before adding any antibiotics. Pour into sterile petri plates near a sterilizing flame (standard Bunsen burner), and then pass flame over the surface of agar to remove any bubbles. Replace the lid. Allow the plates to dry overnight (agar-side down) at room temperature. Re-sleeve, invert, and store up to 1 month at $4^{\circ} \mathrm{C}$.

Tryptic soy broth-For solid medium, dissolve $20 \mathrm{~g}$ Difco tryptic soy agar (soybeancasein digest agar) (Becton Dickinson, cat. no. 236920) with $500 \mathrm{ml} \mathrm{H}_{2} \mathrm{O}$ in a 1000-ml Pyrex bottle. For liquid medium, dissolve $30 \mathrm{~g}$ Bacto tryptic soy broth (soybean-casein digest medium) (Becton Dickinson, cat. no. 211822) with $1000 \mathrm{ml} \mathrm{H}_{2} \mathrm{O}$ in a 1000-ml Pyrex bottle. Autoclave all media at $121^{\circ} \mathrm{C}$ for $15 \mathrm{~min}$. Store up to 6 months at room temperature. 


\section{COMMENTARY}

\section{Background information}

Numerous $S$. aureus isolates have been sequenced and deposited in GenBank. S. aureus genomes encompass up to 2870 genes and display up to $22 \%$ of DNA sequence variability (Baba et al., 2007). The Sanger Institute is leading a large effort on $S$. aureus genome sequencing and comparative genomics, deep sequencing within lineages and sampling populations (Harris et al., 2010; McAdam et al., 2012). Up-to-date details of this program can be found at the following site: http://www.sanger.ac.uk/resources/downloads/bacteria/ staphylococcus-aureus.html.

Genome variability in $S$. aureus isolates is brought about by insertions of transposons and mobile elements, as well as prophages and plasmids. Pathogenicity islands are common and encode toxins associated with specific clinical conditions (toxinoses). Such islands are 15 to $20 \mathrm{kbp}$ DNA elements that occupy constant positions in the chromosomes of toxigenic strains and encompass both phage-related features and flanking direct repeats (Novick and Subedi, 2007). S. aureus clinical isolates are generally categorized as clonal cluster (CC) types, which is accomplished via multi-locus sequence typing (MLST) (Enright et al., 2000).

$S$. aureus strains can cause skin and soft tissue infections, pneumonia, toxic-shock syndrome, exfoliative skin disease, endocarditis, osteomylitis, and enteritis (Lowy, 1998). $S$. aureus is by far the most virulent species in the genus Staphylococcus (Götz et al., 2006). Dissemination among recipient host population occurs via physical contact and aerosols and is probably facilitated by the large population of colonized individuals (25\% to 30\%) (Lowy, 1998). At least $2 \%$ of the population is colonized with MRSA (Gorwitz et al., 2008). Most MRSA isolates carry the SCCmec IV genetic element that confers resistance to $\beta$-lactam antimicrobials (Ma et al., 2002).S. aureus may infect animals, in particular house pets, swine, horse and cattle where it is the causative agent of mastitis. Recent epidemiological studies suggest the emergence and evolution of MRSA in animals (McCarthy et al., 2012).

\section{Critical Parameters and Troubleshooting}

All $S$. aureus clinical isolates must be considered virulent; however, continuous growth of strains on rich medium may lead to loss of virulence by discrete genetic mutations or loss of mobile genomic elements (Somerville et al., 2002). Thus, clinical $S$. aureus isolates should be stored at $-80^{\circ} \mathrm{C}$ as soon as possible. When grown for long periods at temperatures above $42^{\circ} \mathrm{C}(>48 \mathrm{hr}$ ), $S$. aureus acquires mutations that often lead to global loss of virulence by affecting one of the numerous transcriptional regulators of the virulon (Sun et al., 2010). Most allelic replacement and transposition experiments use temperature-sensitive plasmids, necessitating extended growth of the bacterium at $42^{\circ} \mathrm{C}$ (Bae and Schneewind, 2005). Thus, it is necessary to either transduce or complement any allele obtained with such protocols (Bae et al., 2004). Owing to the large variability in the genome, DNA acquisition by bacteriophage transduction or plasmid transformation between different isolates may lead to the recombination of new alleles and acquisition of new traits. 


\section{Anticipated Results}

$S$. aureus grows rapidly in rich medium (doubling time $20 \mathrm{~min}$ ) and yields a yellow colony on plate owing to the production of the carotenoid pigment staphyloxanthin. Although rare, small colony variants (SCVs) of S. aureus have been observed (Proctor et al., 1998). SCVs are defective in electron transport and can be isolated from persistent infections in humans and following infection of tissue cultures (Proctor et al., 1998) or when bacteria are grown under antibiotic stress conditions in vitro (Edwards, 2012).

When grown in culture, $S$. aureus sediments readily and cultures should be shaken vigorously before removing aliquots for optical density (turbidity) measurement. Also, because all staphylococcal cells do not separate from their parents, serial dilutions of even vigorously shaken cultures plated for enumeration of colony forming units may produce erroneously low cell counts.

\section{Time Considerations}

Incubation of liquid cultures or plates for 12 to $16 \mathrm{hr}$ at $37^{\circ} \mathrm{C}$ will yield a saturated culture or clearly visible colony (1-ml cultures typically reach optical densities $\sim 5$ to 6 at $600 \mathrm{~nm}$ following overnight incubation). Many experiments use bacteria grown to exponential phase. This is typically achieved by diluting bacteria from an overnight culture at $1: 100(\mathrm{v} / \mathrm{v})$ in fresh medium. An optical density of 0.4 at $600 \mathrm{~nm}$ with $\sim 1$ to $5 \times 10^{7}$ colony-forming units will be reached within 2 to $3 \mathrm{hr}$ following incubation of the culture at $37^{\circ} \mathrm{C}$. One additional hour of incubation may be necessary if starting from an isolated colony. Plating of serial dilutions must be performed for each isolate to correlate growth and optical densities.

\section{Literature Cited}

Arbeit RD, Maki D, Tally FP, Campanaro E, and Eisenstein BI 2004 The safety and efficacy of daptomycin for the treatment of complicated skin and skin-structure infections. Clin. Infect. Dis 38:1673-1681. [PubMed: 15227611]

Baba T, Bae T, Schneewind O, Takeuchi F, and Hiramatsu K 2007 Genome sequence of Staphylococcus aureus strain Newman and comparative analysis of staphylococcal genomes. J. Bacteriol 190:300-310. [PubMed: 17951380]

Bae T and Schneewind O 2005 Allelic replacement in Staphylococcus aureus with inducible counterselection. Plasmid 55:58-63. [PubMed: 16051359]

Bae T, Banger AK, Wallace A, Glass EM, Aslund F, Schneewind O, and Missiakas DM 2004 Staphylococcus aureus virulence genes identified by bursa aurealis mutagenesis and nematode killing. Proc. Natl. Acad. Sci. U.S.A. 101:12312-12317. [PubMed: 15304642]

Bernheimer AW, Avigad LS, and Grushoff P 1968 Lytic effects of staphylococcal alpha-toxin and delta-hemolysin. J. Bacteriol 96:487-491. [PubMed: 4970650]

Brumfitt W and Hamilton-Miller J 1989 Methicillin-resistant Staphylococcus aureus. N. Engl. J. Med 320:1188-1199. [PubMed: 2651925]

Chang S, Sievert DM, Hageman JC, Boulton ML, Tenover FC, Downes FP, Shah S, Rudrik JT, Pupp GR, Brown WJ, Cardo D, and Fridkin SK 2003 Infection with vancomycin-resistant Staphylococcus aureus containing the vanA resistance gene. N. Engl. J. Med 348:1342-1347. [PubMed: 12672861]

Cheng AG, Kim HK, Burts ML, Krausz T, Schneewind O, and Missiakas DM 2009 Genetic requirements for Staphylococcus aureus abscess formation and persistence in host tissues. FASEB J. 23:3393-3404. [PubMed: 19525403]

Cheng AG, DeDent AC, Schneewind O, and Missiakas D 2011 A play in four acts: Staphylococcus aureus abscess formation. Trends Microbiol. 19:225-232. [PubMed: 21353779] 
de Jonge BLM, Chang YS, Gage D, and Tomasz A 1992 Peptidoglycan composition in heterogeneous Tn551 mutants of a methicillin-resistant Staphylococcus aureus strain. J. Biol. Chem 267:1125511259. [PubMed: 1317861]

Diep BA, Gill SR, Chang RF, Phan TH, Chen JH, Davidson MG, Lin F, Lin J, Carleton HA, Mongodin EF, Sensabaugh GF, and Perdreau-Remington F 2006 Complete genome sequence of USA300, an epidemic clone of community-acquired meticillin-resistant Staphylococcus aureus. Lancet 367:731-739. [PubMed: 16517273]

Dinges MM, Orwin PM, and Schlievert PM 2000 Exotoxins of Staphylococcus aureus. Clin. Microbiol. Rev 13:16-34. [PubMed: 10627489]

Duthie ES 1954 Evidence for two forms of staphylococcal coagulase. J. Gen. Microbiol 10:427-436. [PubMed: 13174765]

Edwards AM 2012 Phenotype-switching is a natural consequence of Staphylococcus aureus replication. J. Bacteriol 194:5404-5412. [PubMed: 22865841]

Enright MC, Day NPJ, Davies CE, Peacock SJ, and Spratt BG 2000 Multilocus sequence typing for characterization of methicillin-resistant and methicillin-susceptible clones of Staphylococcus aureus. J. Clin. Micro-biol. 38:1008-1015.

Forsgren A and Sjöquist J 1966 Protein A from S. aureus. I. Pseudo-immune reaction with human gamma-globulin. J. Immunol 97:822-827. [PubMed: 4163007]

Giesbrecht P, Kersten T, Maidhof H, and Wecke J 1998 Staphylococcal cell wall: Morphogenesis and fatal variations in the presence of penicillin. Microbiol. Mol. Biol. Rev 62:1371-1414. [PubMed: 9841676]

Gillaspy AF, Hickmon SG, Skinner RA, Thomas JR, Nelson CL, and Smeltzer MS 1995 Role of the accessory gene regulator (agr) in pathogenesis of staphylococcal osteomyelitis. Infect. Immun 63:3373-3380. [PubMed: 7642265]

Gorwitz RJ, Kruszon-Moran D, McAllister SK, McQuillan G, McDougal LK, Fosheim GE, Jensen BJ, Killgore G, Tenover FC, and Kuehnert MJ 2008 Changes in the prevalence of nasal colonization with Staphylococcus aureus in the United States, 2001-2004. J. Infect. Dis 197:1226-1234. [PubMed: 18422434]

Götz F, Bannerman T, and Schleifer K-H 2006 The genera Staphylococcus and Macrococcus In The Prokaryotes (Dworkin M, Falkow S, Rosenberg E, Schleifer K-H, and Stacke-brandt E, eds.) pp. 5-75. Springer, New York.

Gründling A and Schneewind O 2007 Synthesis of glycerol phosphate lipoteichoic acid in Staphylococcus aureus. Proc. Natl. Acad. Sci. U.S.A. 104:8478-8483. [PubMed: 17483484]

Harris SR, Feil EJ, Holden MT, Quail MA, Nickerson EK, Chantratita N, Gardete S, Tavares A, Day N, Lindsay JA, Edgeworth JD, de Lencastre H, Parkhill J, Peacock SJ, and Bentley SD 2010 Evolution of MRSA during hospital transmission and intercontinental spread. Science 327:469474. [PubMed: 20093474]

Herold BC, Immergluck LC, Maranan MC, Lauderdale DS, Gaskin RE, Boyle-Vavra S, Leitch CD, and Daum RS 1998 Community-acquired methicillin-resistant Staphylococcus aureus in children with no identified predisposing risk. JAMA 279:593-598. [PubMed: 9486753]

Hiramatsu K, Hanaki H, Ino T, Yabuta K, Oguri T, and Tenover FC 1997 Methicillin-resistant Staphylococcus aureus clinical strain with reduced vancomycin susceptibility. J. Antimicrob. Chemother 40:135-136. [PubMed: 9249217]

Iordanescu S and Surdeanu M 1976 Two restriction and modification systems in Staphylococcus aureus NCTC8325. J. Gen. Microbiol 96:277-281.

Kennedy AD, Otto M, Braughton KR, Whitney AR, Chen L, Mathema B, Mediav illa JR, Byrne KA, Parkins LD, Ten-over FC, Kreiswirth BN, Musser JM, and DeLeo FR 2008 Epidemic communityassociated methicillin-resistant Staphylococcus aureus: Recent clonal expansion and diversification. Proc. Natl. Acad. Sci. U.S.A. 105:1327-1332. [PubMed: 18216255]

Kreiswirth BN, Lofdahl S, Betley MJ, O'Reilly M, Schlievert PM, Bergdoll MS, and Novick RP 1983 The toxic shock syndrome exotoxin structural gene is not detectably transmitted by a prophage. Nature 305:709-712. [PubMed: 6226876]

Kuroda M, Ohta T, Uchiyama I, Baba T, Yuzawa H, Kobayashi L, Cui L, Oguchi A, Aoki K, Nagai Y, Lian J, Ito T, Kanamori M, Matsumaru H, Maruyama A, Murakami H, Hosoyama A, Mizutani-Ui 
Y, Takahashi NK, Sawano T, Inoue R, Kaito C, Sekimizu K, Hirakawa H, Kuhara S, Goto S, Yabuzaki J, Kanehisa M, Yamashita A, Oshima K, Furuya K, Yoshino C, Shiba T, Hattori M, Ogasawara N, Hayashi H, and Hiramatsu K 2001 Whole genome sequencing of methicillinresistant Staphylococcus aureus. Lancet 357:1225-1240. [PubMed: 11418146]

Lee CY and Iandolo JJ 1986 Integration of staphylococcal phage L54a occurs by site-specific recombination: Structural analysis of the attachment sites. Proc. Natl. Acad. Sci. U.S.A. 83:54745478. [PubMed: 2942938]

Lee CY, Buranen SL, and Ye Z-H 1991 Construction of single-copy integration vectors for Staphylococcus aureus. Gene 103:101-105. [PubMed: 1652539]

Loeb L 1903 The Influence of certain bacteria on the coagulation of the blood. J. Med. Res 10:407419. [PubMed: 19971581]

Lowy FD 1998 Staphylococcus aureus infections. N. Engl. J. Med 339:520-532. [PubMed: 9709046]

Ma XX, Ito T, Tiensasitorn C, Jamklang M, Chongtrakool P, Boyle-Vavra S, Daum RS, and Hiramatsu K 2002 Novel type of staphylococcal cassette chromosome mec identified in community-acquired methicillin resistant Staphylococcus aureus strains. Antimicrob. Agents Chemother. 46:11471152. [PubMed: 11897611]

McAdam PR, Templeton KE, Edwards GF, Holden MT, Feil EJ, Aanensen DM, Bargawi HJ, Spratt BG, Bentley SD, Parkhill J, Enright MC, Holmes A, Girvan EK, Godfrey PA, Feldgarden M, Kearns AM, Rambaut A, Robinson DA, and Fitzgerald JR 2012 Molecular tracing of the emergence, adaptation, and transmission of hospital-associated methicillin-resistant Staphylococcus aureus. Proc. Natl. Acad. Sci. U.S.A. 109:9107-9112. [PubMed: 22586109]

McCarthy AJ, Lindsay JA, and Loeffler A 2012 Are all meticillin-resistant Staphylococcus aureus (MRSA) equal in all hosts? Epidemiological and genetic comparison between animal and human MRSA. Vet. Dermatol 23:267-275. [PubMed: 22823579]

Miller JH 1992 A Short Course in Bacterial Genetics Cold Spring Harbor Laboratory Press, New York.

Much H 1908 Über eine vorstufe des fibrinfermentes in kulturen von Staphylokokkus aureus. Biochem. Z 14:143-155.

Neu HC 1992 The crisis in antibiotic resistance.Science 257:1064-1073. [PubMed: 1509257]

Novick R 1967 Properties of a cryptic high-frequency transducing phage in Staphylococcus aureus. Virology 33:155-166. [PubMed: 4227577]

Novick RP 1990 The Staphylococcus as a molecular genetic system In Molecular Biology of the Staphylococci (Novick RP, ed.) pp. 1-40. VCH Publishers, New York.

Novick RP and Subedi A 2007 The SaPIs: Mobile pathogenicity islands of Staphylococcus. Chem. Immunol. Allergy 93:42-57. [PubMed: 17369699]

Novick RP and Geisinger E 2008 Quorum sensing in staphylococci. Annu. Rev. Genet 42:541-564. [PubMed: 18713030]

O'Riordan K and Lee JC 2004 Staphylococcus aureus capsular polysaccharides. Clin. Micro-biol. Rev 17:218-234.

Ogston A 1883 Micrococcus poisoning. J. Anat. Physiol 17:24-58.

Proctor RA, Kahl B, von Eiff C, Vaudaux PE, Lew DP, and Peters G 1998 Staphylococcal small colony variants have novel mechanisms for antibiotic resistance. Clin. Infect. Dis 27:S68-S74. [PubMed: 9710673]

Reizer J, Hoischen C, Titgemeyer F, Rivolta C, Rabus R, Stulke J, Karamata D, Saier MH, Jr., and Hillen W 1998 A novel protein kinase that controls carbon catabolite repression in bacteria. Mol. Microbiol 27:1157-1169. [PubMed: 9570401]

Rosenbach FJ 1884 Mikroorganismen bei den Wundinfections-Krankheiten des Menschen. Wiesbaden, Germany

Rosenstein R and Gotz F 2000 Staphylococcal lipases: Biochemical and molecular characterization. Biochimie 82:1005-1014. [PubMed: 11099797]

Rudin L, Sjostrom JE, Lindberg M, and Philip-son L 1974 Factors affecting competence for transformation in Staphylococcus aureus. J. Bacteriol 118:155-164. [PubMed: 4274456]

Sambrook J and Russell DW 2006 The Condensed Protocols from Molecular Cloning: A Laboratory Manual Cold Spring Harbor Laboratory Press, Cold Spring Harbor, N.Y. 
Schlag S, Nerz C, Birkenstock TA, Altenberend F, and Götz F 2007 Inhibition of staphylococcal biofilm formation by nitrite. J. Bacteriol 189:7911-7919. [PubMed: 17720780]

Somerville GA, Beres SB, Fitzgerald JR, DeLeo FR, Cole RL, Hoff JS, and Musser JM 2002 In vitro serial passage of Staphylococcus aureus: Changes in physiology, virulence factor production, and agr nucleotide sequence. J. Bacteriol 184:1430-1437. [PubMed: 11844774]

Stevens DH, Herr D, Campiris H, Hunt JL, Batts DH, and Hafkin B 2002 Linezolid versus vancomycin for the treatment of methicillin-resistant Staphylococcus aureus infections. Clin. Infect. Dis 34:1481-1490. [PubMed: 12015695]

Sun F, Cho H, Jeong DW, Li C, He C, and Bae T 2010 Aureusimines in Staphylococcus aureus are not involved in virulence. PLoS One 5:e15703. [PubMed: 21209955]

Tzagoloff H and Novick R 1977 Geometry of cell division in Staphylococcus aureus. J. Bacteriol 129:343-350. [PubMed: 830642]

van Hal SJ and Paterson DL 2011 New Gram-positive antibiotics: Better than vancomycin? Curr. Opin. Infect. Dis 24:515-520. [PubMed: 21844804]

Vandenesch F, Kornblum J, and Novick RP 1991 A temporal signal, independent of agr, is required for hla but not spa transcription in Staphylococcus aureus. J. Bacteriol 173:6313-6320. [PubMed: 1717437]

von Eiff C, Heilmann C, Proctor RA, Woltz C, Peters G, and Gotz F 1997 A site-directed Staphylococcus aureus hemB mutant is a small-colony variant which persists intracellularly. J. Bacteriol 179:4706-4712. [PubMed: 9244256]

Waldron DE and Lindsay JA 2006 Sau1: A novel lineage-specific type I restriction-modification system that blocks horizontal gene transfer into Staphylococcus aureus and between $S$. aureus isolates of different lineages.J. Bacteriol 188:5578-5585. [PubMed: 16855248]

Walsh CT 1993 Vancomycin resistance: Decoding the molecular logic. Science 261:308-309. [PubMed: 8392747]

Wang R, Braughton KR, Kretschmer D, Bach TH, Queck SY, Li M, Kennedy AD, Dor-ward DW, Klebanoff SJ, Peschel A, DeLeo FR, and Otto M 2007 Identification of novel cytolytic peptides as key virulence determinants for community-associated MRSA. Nat. Med 13:1510-1514. [PubMed: 17994102]

Weigel LM, Clewell DB, Gill SR, Clark NC, McDougal LK, Flannagan SE, Kolonay JF, Shetty J, Killgore GE, and Tenover FC 2003 Genetic analysis of a high-level vancomycin-resistant isolate of Staphylococcus aureus. Science 302:1569-1571. [PubMed: 14645850] 
Table 9C.1.1

Antibiotic Usage for $S$. aureus

\begin{tabular}{lcc}
\hline Antibiotic $^{\boldsymbol{a}}$ & Range of final concentration $(\boldsymbol{\mu g} / \mathbf{m l})^{\boldsymbol{b}}$ & Stock $(\mathbf{m g} / \mathbf{m l})^{\boldsymbol{c}}$ \\
\hline Chloramphenicol & $10-20$ & 20 \\
Tetracycline & $5-10$ & 10 \\
Spectinomycin & $10-20$ & 20 \\
Erythromycin & $5-50$ & 50 \\
Kanamycin & $20-25$ & 25 \\
\hline
\end{tabular}

${ }^{a}$ List of the most commonly used antibiotics.

$b$

$b$ The specific concentration of antibiotic may vary depending on the strain (owing to intrinsic resistance) and increases with the copy number of the cognate resistance marker (chromosome: single copy; plasmid: multiple copies).

${ }^{c}$ All antibiotics are acquired as powder products; they are weighed, dissolved, filtered, and stored. Antibiotics stocks may be stored frozen at $-20^{\circ} \mathrm{C}$ for several months or kept at $4{ }^{\circ} \mathrm{C}$ for several weeks. Stocks should not be re-frozen and should be kept on ice when not stored at $4^{\circ} \mathrm{C}$.

Chloramphenicol and erythromycin are dissolved in 100\% ethanol. Tetracycline is dissolved in $70 \%$ ethanol and should be kept in the dark because it is light-sensitive. Spectinomycin and kanamycin are both dissolved in water. Methods to prepare and store antibiotic solutions can be found in manuals for molecular genetics and molecular biology work (Miller, 1992; Sambrook and Russell, 2006). 